\title{
A Comparative Analysis of Financial Performance: Indonesia And Taiwan Urban Railways
}

\author{
Sudarmawan Samidi ${ }^{1 *}$ \\ ${ }^{1}$ Sekolah Tinggi Manajemen Ipmi, Jakarta, Indonesia 12750
}

\begin{abstract}
A B S T R A C T
In countries with government-owned railways, the subsidies required to maintain service were becoming a serious burden on the state. Declining revenues have left the rail industry struggling to overcome operating deficits and to reduce subsidies from governments. This study aims to analyze the financial performance of Indonesia and Taiwan urban rail system. Financial ratios are employed to measure the profitability, liquidity, activity, and solvency performance of PT. Kereta Api Indonesia (KAI) and Taiwan High Speed Rail (THSR). The data were collected from both companies in the period of 2011-2015 based on its audited financial report. In addition, the Decree No. KEP-100/MBU/2002 issued by Indonesia Ministry of SOEs was used to validate the financial health condition with the level of financial assessment. The result showed that KAI had better financial performance in comparison with THSR. Generally, both companies have a challenge in asset utilization and inventory management. Therefore, this study is useful for the managers to tackle the challenges and improve its efficiency. Furthermore, this study could be policy options might be taken to improve both urban railways' performance.
\end{abstract}

ART ICLE INFO

Keywords:

Financial Performance,

Government-Owned Railways,

Urban Railways,

High-Speed Railways. permits unrestricted use, distribution, and reproduction in any medium, provided the original work is properly cited.

\section{INTRODUCTION}

Typical urban transport systems have its own characteristic advantages and disadvantages include high-speed railways, monorails, AGTs, tramways, LRTs, buses, private motor vehicle, bicycles, etc. Takatsu (2003) stated that the introduction of a city transport system requires careful analysis of the transport and technical characteristic along with the scale of the city, the transport objective and demand to ensure that the best system is selected. At the end of the $20^{\text {th }}$ century, many countries adopted radical reforms in an attempt to strengthen their railways. Many countries have attempted to improve the performance of their railways since 1980 by 
introducing or strengthening competitive or market force. The high-speed rail (HSR) system has been proven to be a safe, comfortable, and efficient transportation mode (Ardun and $\mathrm{Ni}$, 2005). Cheng (2010) also state that the ability to carry large numbers of passengers and provide short travel times made HSR as one of the major tools to alleviate the traffic burden of some main traffic corridors in Japan, France, Germany, Spain, and also recently in South Korea and Taiwan.

Nevertheless, the railways' share of passenger and freight traffic had been declining due to increasing competition from autos, buses, airplanes, trucks, and waterways (Gómez-Ibáñez and Ginés de Rus, 2006). In countries with government-owned railways, such as Indonesia and Taiwan, the subsidies required to maintain service were becoming a serious burden on the state. Declining revenues have left the rail industry in Indonesia and Taiwan struggling to overcome operating deficits and to reduce subsidies from governments. With their own set of financial problems, governments have cut subsidies to rail operators, leading to further decline in ridership (Mizutani, F. \& Shoji, K., 1997). Aside from its obligation as the only railway operator in Indonesia, PT Kereta Api Indonesia (KAI) claimed their loss of Rp80 billion in 2008. In 2000-2008, the company's asset also kept decreasing, hence affected to company's profit. Similar to Indonesia, a year after Taiwan High Speed Rail (THSR) operation, the crisis rescission arouses affecting to company's loss. In 2010, due its financial performance, government took the majority control of the company. In the same year, the accumulated loss already exceeded NT $\$ 70$ billion or Rp30 trillion.

Washington (2001) stated that research on the ability of financial models to provide an early warning of corporate failure is favorable. In addition, Daryanto and Nurfadilah (2018) stated that financial ratio is useful to measure the performance of company and it can be used to predict the failure. The users of business information are often stakeholders who rely heavily on financial reports. Lan (2012) stated that ratio analysis is one of the most widely used fundamental analysis techniques. Ratio analysis is a tool that was developed to perform quantitative analysis on numbers found on financial statements. The study about financial performance has been discussed in many sectors (Daryanto and Samidi, 2018). Ratios help link the three financial statements together and offer figures that are comparable between companies and across industries and sectors. Therefore, this study addresses the financial performance of Indonesia and Taiwan urban rail systems. This study consists of five parts, namely part 1 present the introduction, part 2 overview the literature, part 3 discuss the research methodology, part 4 analyze the finding, and part 5 conclude the research and give recommendation for further research.

\section{LITERATURE REVIEW}

\section{Urban Railways in Indonesia and Taiwan}

The national railways of many Asian countries have a lot of tracks that were built during the old colonial period. The Dutch colonial built the first railroad in Indonesia in 1864. After Dutch colonialism was ended, the railway system was taken over by Japan Government. Then, after the independency in 1945, the GOI took over it. By the round table conference, it was agreed that all of the assets of railway are belong to GOI and was regulated in Law No. 23/2007. It stated that as mass transportation that could be differentiate to another transportation system, railways industry in Indonesia should be developed in order to drive national development of social welfare. Railway system in Indonesia is entirely regulated by government with PT Kereta Api Indonesia (KAI) as the operator. Since its establishment in 1945 as Angkatan Moeda Kereta Api, KAI has become stateowned enterprise which the majority of the equity is owned by Ministry of State-Owned Enterprises as the representative of the Government of Indonesia (GOI) (Dirjen Perkeretaapian). Over the years, KAI has become the only player in the railways industry in Indonesia. But starting in 2007, which was stated in the Indonesian Railways Law, the GOI had opened private investment. Then, PT Monorail Jakarta and PT Mass Rapid Transit Jakarta were established. 
Similar to Indonesia, the railway industry in Taiwan had brought by the Japan colonialism. There are two main railway operators in Taiwan, Taiwan Rail Administrator (TRA) and Taiwan High Speed Rail (THSR). TRA is the fully state-owned company, while THSR owned by state and private sector. THSR established in the late of 1990s through consortium between government and private sector. THSR started the construction of high-speed rail system in 2000 and began the operation in 2007. In 2015, THSR had 50,532 train services with punctuality 99.66 per cent, defined as departure within five minutes of schedule time. Annually, the number of passenger or ridership was 50.56 million with 11 cities or counties passed through from Taipei to Zuoying.

Previous Research on Financial Performance

Financial ratio is a good evaluation method to measure the company performances (Megaladevi, 2015). Company usually uses this method to compare their performance with other competitors. Yet, there are still limited number of the researches that focusing on railway transportation. There are two methods to measure the financial performances which are accounting and market measurement. There are many researchers who prefer to use accounting measurement (Waddock and Graves 1997; Cochran and Wood 1984), rather than market measurement (Alexander and Buchholz, 1978; Vance, 1975), and some of them adopt both methods (McGuire et al, 1988). There are few differences between accounting and market measurement method. In accounting, company use the historical aspects to measure their financial performance (McGuire et al, 1986) and it contains a bias which lead to managerial manipulation. On the other hand, market measurement method is straight forward, focus on performance and represent the ability of a company to generate future income (McGuire et al, 1988). However, the research used financial ratio analysis has increased over the past years (Kumbirai \& Webb, 2010).

According to Pratama (2017), the use of financial ratio in measurement of financial performance adopted by the Decree of Ministry SOEs Republic of Indonesia (RI) No. KEP-100/MBU/2002 about financial health assessment which stated that the growth of business should be supported by good infrastructure and evaluation system to measure the efficiency and level of competition among SOEs. This financial evaluation applies to all state-owned enterprises in the financial and nonfinancial industry. There are eight indicators to measure the financial health as described in table 1.

Table 1. The Indicators and Weight Score

\begin{tabular}{|c|l|c|}
\hline No & \multicolumn{1}{|c|}{ Indicators } & Weight Score \\
\hline 1 & ROE & 20 \\
\hline 2 & ROI & 15 \\
\hline 3 & Cash Ratio & 5 \\
\hline 4 & Current Ratio & 5 \\
\hline 5 & Collection Period & 5 \\
\hline 6 & Inventory Turnover & 5 \\
\hline 7 & Total Asset Turnover & 5 \\
\hline 8 & Total Equity to Total Asset & 10 \\
\hline \multicolumn{2}{|c|}{ Total weight score } & $\mathbf{7 0}$ \\
\hline
\end{tabular}

Source: The decree of Ministry of SOEs RI, No. KEP 100/MBU/2002

\section{RESEARCH METHOD}

The descriptive financial ratio was used to measure and analyse the performance of KAI and THSR. Data were collected from Annual Report (audited) of both companies between 2011 and 2015. All variables used are ratio measurement scales were taken from the decree of Ministry of SOEs No. KEP-100/MBU/2002 about the financial health assessments. The decree was used to validate the financial health condition with the level of financial assessment. The level of financial assessment is divided into very healthy (AAA, AA, $A)$, healthy (BBB, BB, B), and unhealthy ( $C C C, C C, C)$. In the highest category, there are three types of levels such as AAA (if the total weight score is more than 95 points), AA (if the total weight score is more than 80 and less than 95), and $\mathrm{A}$ (if the total weight score is more than 65 and less than 80). In the middle category, there are three types of levels such as BBB (if it is more than 50 and less than 65), BB (if it is more than 40 and less than 50), and B (if it is more than 30 and less than 40). In the lowest category, there are three types 
of levels such as CCC (if it is more than 20 and less than 30), CC (if it is more than 10 and less than 20), and C (if it is less than 10). Here are the variables and weight score:

The profitability is the most common measure for company's financial performance. Profitability is measured as Return on Equity (ROE) $=\left(\frac{\text { Net thoome }}{\text { Shareholders' Equity }}\right)$ $x 100 \%$ Return on equity is an important ratio for investors to consider its profits. ROE measures how efficiently a company can use the money from shareholders to generate profits and grow the company (Anthony, 2011). In addition, return on investment (ROI) is a profitability ratio that calculates the profits of an investment as a percentage of the original cost. The equation of ROI can be expressed as Return on Investment $(R O I)=\left(\frac{\text { EBIT IDepreciation }}{\text { Capital Employed }}\right) \times 100 \%$ Table 2 shows the ROE and ROI Assessment Score.

Table 2. List of ROE and ROI Assessment Score

\begin{tabular}{|c|c|c|c|}
\hline ROE (\%) & Score & ROI (\%) & Score \\
\hline $15<\mathrm{ROE}$ & 20 & $18<\mathrm{ROI}$ & 15 \\
\hline $13<\mathrm{ROE}<=15$ & 18 & $15<\mathrm{ROI}<=18$ & 13,5 \\
\hline $11<\mathrm{ROE}<=13$ & 16 & $13<\mathrm{ROI}<=15$ & 12 \\
\hline $9,0<\mathrm{ROE}<=11$ & 14 & $12<\mathrm{ROI}<=13$ & 10,5 \\
\hline $7,9<\mathrm{ROE}<=9$ & 12 & $10,5<\mathrm{ROI}<=12$ & 9 \\
\hline $6,6<\mathrm{ROE}<=7,9$ & 10 & $9<\mathrm{ROI}<=10,5$ & 7,5 \\
\hline $5,3<\mathrm{ROE}<=6,6$ & 8,5 & $7<\mathrm{ROI}<=9$ & 6 \\
\hline $4,0<\mathrm{ROE}<=5,3$ & 7 & $5<\mathrm{ROI}<=7$ & 5 \\
\hline $2,5<\mathrm{ROE}<=4$ & 5,5 & $3<\mathrm{ROI}<=5$ & 4 \\
\hline $1,0<\mathrm{ROE}<=2,5$ & 4 & $1<\mathrm{ROI}<=3$ & 3 \\
\hline $0<\mathrm{ROE}<=1$ & 2 & $0<\mathrm{ROI}<=1$ & 2 \\
\hline $\mathrm{ROE}<0$ & 0 & $\mathrm{ROI}<0$ & 1 \\
\hline
\end{tabular}

Source: The decree of Ministry of SOEs RI, No. KEP-100/MBU/2002.

\section{Liquidity Performance}

The liquidity performance measures the company ability to pay its short-term debt. It can be expressed as Cash Ratio $=\left(\frac{\text { Casht+ash Equivalents }}{\text { Cuurrent Liabilities }}\right) \times 100 \%$ If the company has cash ratio equal to 1 , it indicates that company has the same amount of cash and its debt. If the value of cash ratio is more than 1 , it indicates that company has more cash to pay its debt. However, if the value is less than 1 , it indicates that company has less cash to pay its debt. In addition, it measures the company ability to repay its current liability with current asset as expressed as Current Ratio $=\left(\frac{\text { Current Asset }}{\text { Currentiabilities }}\right) \times 100 \%$ If the company has current ratio below 1 , it indicates that company has problem with its short-term debt. If the company has too high current ratio, it indicates that company has problem in managing their current asset. Table 3 shows the Cash Ratio and Current Ratio Assessment Score.

Table 3. List of Cash Ratio and Current Ratio Assessment Score

\begin{tabular}{|c|c|c|c|}
\hline Cash Ratio = x (\%) & Score & $\begin{array}{c}\text { Current } \\
\text { Ratio = x (\%) }\end{array}$ & Score \\
\hline $\mathrm{x}>=35$ & 5 & $125<=\mathrm{x}$ & 5 \\
\hline $25<=\mathrm{x}<35$ & 4 & $110<=\mathrm{x}<125$ & 4 \\
\hline $15<=\mathrm{x}<25$ & 3 & $100<=\mathrm{x}<110$ & 3 \\
\hline $10<=\mathrm{x}<15$ & 2 & $95<=\mathrm{x}<100$ & 2 \\
\hline $5<=\mathrm{x}<10$ & 1 & $90<=\mathrm{x}<95$ & 1 \\
\hline $0<=\mathrm{x}<5$ & 0 & $\mathrm{x}<90$ & 0 \\
\hline
\end{tabular}

Source: The decree of Ministry of SOEs RI, No. KEP-100/MBU/2002.

\section{Activity Performance}

The activity ratios measure the company sales per another asset account (account receivable, inventory and total assets). It also measures the efficiency of the company in using its resources. First, Collection Period $=\left(\frac{\text { Average Accounts Receivables }}{\text { Sales Revenue }}\right) \times 365$ days. This ratio is an important indicator for company to monitor their cash flow and the company ability to pay its debt in due date. Second, Inventory Turnover $=\left(\frac{\text { cost of Goods Sold }}{\text { Averagelinventory }}\right)$. This ratio measures how many times the inventory is being sold of a certain period of time. Third, Total Asset Turnover $=\left(\frac{\text { Revenue }}{\text { Capital Employed }}\right) \times 100 \%$. This ratio measures the company ability to measure the efficiency to use its asset to generate sales.

Table 5. List of Total Asset Turn-Over Assessment Score

\begin{tabular}{|c|c|c|}
\hline TATO $=$ x (\%) & $\begin{array}{c}\text { Adjustment }= \\
\text { x (days) }\end{array}$ & Score \\
\hline $120<x$ & $20<x$ & 5 \\
\hline $105<x<=120$ & $15<x<=20$ & 4,5 \\
\hline $90<x<=105$ & $10<x<=15$ & 4 \\
\hline $75<x<=90$ & $5<x<=10$ & 3,5 \\
\hline $60<x<=75$ & $0<x<=5$ & 3 \\
\hline $40<x<=60$ & $x<=0$ & 2,5 \\
\hline $20<x<=40$ & $x<0$ & 2 \\
\hline$x<=20$ & $x<0$ & 1,5 \\
\hline
\end{tabular}

Source: The decree of Ministry of SOEs RI, No. KEP-100/MBU/2002. 
Table 4. List of Collection Period and Inventory Turnover Assessment Score

\begin{tabular}{|c|c|c|c|c|c|}
\hline $\begin{array}{c}\text { Collection } \\
\text { Period = x (days) }\end{array}$ & $\begin{array}{c}\text { Adjustment } \\
\mathbf{x} \text { (days) }\end{array}$ & Score & $\begin{array}{c}\text { Inventory Turnover } \\
=\mathbf{x} \text { (days) }\end{array}$ & $\begin{array}{c}\text { Adjustment }=\mathbf{x} \\
\text { (days) }\end{array}$ & Score \\
\hline $\mathrm{x} \leq 60$ & $30<\mathrm{x}$ & 5 & $\mathrm{x}<=60$ & $30<\mathrm{x}$ & 5 \\
\hline $60<\mathrm{x}<=90$ & $30<\mathrm{x}<=35$ & 4.5 & $60<\mathrm{x}<=90$ & $30<\mathrm{x}<=35$ & 4.5 \\
\hline $90<\mathrm{x}<=120$ & $25<\mathrm{x}<=30$ & 4 & $90<\mathrm{x}<=120$ & $25<\mathrm{x}<=30$ & 4 \\
\hline $120<\mathrm{x}<=150$ & $20<\mathrm{x}<=25$ & 3.5 & $120<\mathrm{x}<=150$ & $20<\mathrm{x}<=25$ & 3.5 \\
\hline $150<\mathrm{x}<=180$ & $15<\mathrm{x}<=20$ & 3 & $150<\mathrm{x}<=180$ & $15<\mathrm{x}<=20$ & 3 \\
\hline $180<\mathrm{x}<=210$ & $10<\mathrm{x}<=15$ & 2.4 & $180<\mathrm{x}<=210$ & $10<\mathrm{x}<=15$ & 2.4 \\
\hline $210<\mathrm{x}<=240$ & $6<\mathrm{x}<=10$ & 1.8 & $210<\mathrm{x}<=240$ & $6<\mathrm{x}<=10$ & 1.8 \\
\hline $240<\mathrm{x}<=270$ & $3<\mathrm{x}<=6$ & 1.2 & $240<\mathrm{x}<=270$ & $3<\mathrm{x}<=6$ & 1.2 \\
\hline $270<\mathrm{x}<=300$ & $1<\mathrm{x}<=3$ & 0.6 & $270<\mathrm{x}<=300$ & $1<\mathrm{x}<=3$ & 0.6 \\
\hline $300<\mathrm{x}$ & $0<\mathrm{x}<=1$ & 0 & $300<\mathrm{x}$ & $0<\mathrm{x}<=1$ & 0 \\
\hline
\end{tabular}

Source: The decree of Ministry of SOEs RI, No. KEP-100/MBU/2002.

\section{Solvency Performance}

This ratio is similar with debt to equity ratio. If the company has less value, it indicates that company funding its asset inefficiently. In the other words, company has very low net value for investor. It can be expressed as Total Equity to TotalAsset $=\quad x 100 \%$.

Table 6. List of Solvency Assessment Score

\begin{tabular}{|c|c|}
\hline $\begin{array}{c}\text { Total Equity to Total } \\
\text { Asset }(\%)=\mathbf{x}\end{array}$ & Score \\
\hline $\mathrm{x}<0$ & 0 \\
\hline $0<=\mathrm{x}<10$ & 4 \\
\hline $10<=\mathrm{x}<20$ & 6 \\
\hline $20<=\mathrm{x}<30$ & 7,25 \\
\hline $30<=\mathrm{x}<40$ & 10 \\
\hline $40<=\mathrm{x}<50$ & 9 \\
\hline $50<=\mathrm{x}<60$ & 8,5 \\
\hline $60<=\mathrm{x}<70$ & 8 \\
\hline $70<=\mathrm{x}<80$ & 7,5 \\
\hline $80<=\mathrm{x}<90$ & 7 \\
\hline $90<=\mathrm{x}<100$ & 6,5 \\
\hline
\end{tabular}

Source: The decree of Ministry of SOEs RI,

No. KEP-100/MBU/2002.

\section{RESULT AND DISCUSSION}

In examining the level of financial health of both companies, whether it is in very healthy, healthy or unhealthy position from 2011-2015, the decree of the Ministry of SOEs RI, No. KEP-100/MBU/2002 is employed.

\section{Profitability Performance}

Table 7 and 8 show the calculation of the return on equity of KAI and THSR in the period of 2011 to 2015. THSR showed the greater ROE in the final year of 2015 compared to PT KAI, 34.67 per cent to 16.64 per cent. In 2011, both of the companies were in their bottom out. In $t$ he following year, both KAI and THSR were slightly increasing to, respectively, 7.99 per cent and 11.04 per cent. A decrease for both companies occurred in 2013. KAI slightly dipped to 6.48 per cent, while THSR fell to 7.63. The enormous increase happened in 2015 for THSR, when it rose up to 34.67 per cent in 2015 from 12.25 per cent in 2014. KAI also climbed up to 16.64 per cent in 2015 from 13.62 per cent in 2014. In conclusion, in 2015, both KAI and THSR had very good achievement since their return on equity exceeds the minimum standard of the Decree which is 15 percent.

Table 7 and 8 show the calculation of the return on investment for KAI and THSR which is shown that KAI has higher ROI than THSR in every year, except in 2011. THSR reached its peak in 2011, showing a number of 28.83 per cent on its ROI. Meanwhile, KAI started the year in 9.99 per cent of ROI. In the following year, THSR dramatically fell to 0.97 per cent. For the next following years, until 2014, the ROI remained under 1 per cent. In 2015, THSR finally reached 4.01 per cent. On the other hand, KAI reached its peak in 2012 in 14.16 per cent. Then, in the next following years, had decreasing to 10.49 per cent but slowly rose to 12.44 per cent in 2014 and 13.07 in 2015. In sum, 
Table 7. The Result for PT Kereta Api Indonesia (KAI) 2011-2015

\begin{tabular}{|c|c|c|c|c|c|c|c|c|c|c|}
\hline \multirow{2}{*}{ Indicators } & \multicolumn{2}{|c|}{2015} & \multicolumn{2}{|c|}{2014} & \multicolumn{2}{|c|}{2013} & \multicolumn{2}{|c|}{2012} & \multicolumn{2}{|c|}{2011} \\
\hline & Value & Score & Value & Score & Value & Score & Value & Score & Value & Score \\
\hline ROE (\%) & 16.64 & 15 & 13.62 & 13.5 & 6.48 & 8.5 & 7.99 & 9 & 5.10 & 6 \\
\hline ROI (\%) & 13.70 & 8 & 12.44 & 7 & 10.49 & 5 & 14.16 & 8 & 9.99 & 5 \\
\hline Cash Ratio (\%) & 36.23 & 3 & 35.96 & 3 & 43.13 & 3 & 50.34 & 3 & 47.73 & 3 \\
\hline Current Ratio (\%) & 110.67 & 2.5 & 72.59 & 0 & 97.16 & 1.5 & 116.73 & 2.5 & 147.42 & 3 \\
\hline CP (days) & 12.94 & 4 & 10.91 & 4 & 11.07 & 4 & 15.13 & 4 & 14.23 & 4 \\
\hline ITO (days) & 16.18 & 4 & 11.38 & 4 & 7.34 & 4 & 8.01 & 4 & 8.26 & 4 \\
\hline TATO (\%) & 83.00 & 2.5 & 83.00 & 2.5 & 65 & 2 & 103 & 3 & 121 & 4 \\
\hline Solvency (\%) & 40.58 & 5.5 & 40.99 & 5.5 & 39.22 & 6 & 59.41 & 5 & 65.08 & 4.5 \\
\hline Total & \multicolumn{2}{|c|}{44.5} & \multicolumn{2}{|c|}{39.5} & \multicolumn{2}{|c|}{34} & \multicolumn{2}{|c|}{38.5} & \multicolumn{2}{|c|}{33.5} \\
\hline
\end{tabular}

Table 8. The Result for Taiwan High Speed Railway (THSR) 2011-2015

\begin{tabular}{|c|c|c|c|c|c|c|c|c|c|c|}
\hline \multirow{2}{*}{ Indicators } & \multicolumn{2}{|c|}{2015} & \multicolumn{2}{|c|}{2014} & \multicolumn{2}{|c|}{2013} & \multicolumn{2}{|c|}{2012} & \multicolumn{2}{|c|}{2011} \\
\hline & Value & Score & Value & Score & Value & Score & Value & Score & Value & Score \\
\hline ROE (\%) & 34.67 & 15 & 12.25 & 12 & 7.63 & 7.5 & 11.04 & 12 & 1.36 & 3 \\
\hline ROI (\%) & 4.01 & 3 & 0.55 & 2 & 0.56 & 2 & 0.97 & 10 & 28.83 & 10 \\
\hline Cash Ratio (\%) & 5.94 & 1 & 12.12 & 1.5 & 20.04 & 2 & 19.39 & 2 & 0.85 & 0 \\
\hline Current Ratio (\%) & 166.37 & 3 & 521.35 & 3 & 531.02 & 3 & 506.18 & 3 & 1962.00 & 3 \\
\hline CP (days) & 1.48 & 4 & 2.15 & 4 & 3.63 & 4 & 3.88 & 4 & 2.83 & 4 \\
\hline ITO (days) & 15.15 & 4 & 26.55 & 4 & 29.18 & 4 & 32.29 & 4 & 35.38 & 4 \\
\hline TATO (\%) & 11.03 & 0 & 7.85 & 0 & 7.33 & 0 & 8.28 & 0 & 13.36 & 0 \\
\hline Solvency (\%) & 11.89 & 3 & 8.98 & 2 & 8.62 & 2 & 7.75 & 2 & 6.78 & 2 \\
\hline Total & \multicolumn{2}{|c|}{33} & \multicolumn{2}{|c|}{28.5} & \multicolumn{2}{|c|}{24.5} & \multicolumn{2}{|c|}{37} & \multicolumn{2}{|c|}{26} \\
\hline
\end{tabular}

both KAI and THSR could not meet the minimum standard of the Decree, which is 18 per cent for ROI.

\section{Liquidity Performance}

As per shown in table 7 and 8 KAI has higher cash ratio compared to THSR in every year from 2011 to 2015. In 2015, THSR was in its lowest point in 0.85 per cent and then had dramatic increase in the following year to 19.39 per cent. In 2014, THSR slightly increased to 20,04 per cent and then fell down to 12.12 per cent in 2014 . Finally, in 2015, THSR dropped again to 5.94 per cent. Meanwhile, KAI reached its peak in 2012 to 50.35 per cent from 47.74 per cent in 2011. Then, for two years, KAI fell down to 43.13 per cent in 2013 and 35.96 per cent in 2014. The company had small increased in 2015 to 36.23 per cent. To conclude, THSR was not meet the minimum standard of the Decree which is 45 per cent of cash ratio. It means, the company did not have enough cash to pay its short-term debt. Meanwhile, KAI showed a high cash ratio and meet the minimum standard of the Decree. KAI had enough cash to pay its short-term debt and still have cash remaining.

Table 7 and 8 show THSR had higher current ratio than KAI from 2012 to 2015. In 2011, THSR was in its lowest point in 19.62 per cent. Meanwhile, KAI was in 147 per cent. The next following year, THSR dramatically rose to 506.18 per cent and until 2014, the percentage remain steadily in 531.02 per cent in 2013 and 521.35 in 2014. But in 2015, the company had huge drop to 166.37 per cent. On the other hand, for three years from 2012 to 2014, KAI slowly decreased to 73 per cent and then had moderate rise in 2015 to 111 per cent. Overall, KAI could not meet the minimum standard of the decree which is 125 per cent while THSR is far below the minimum standard. This means, even though THSR does not have enough cash and equivalent to pay its short-term debt, the company has enough asset to pay. In contrast, KAI has enough cash and 
equivalent to pay its short-term debt but when it is calculated with all its asset, the company seems have little difficulty paying its short-term debt since the ratio is slightly below the minimum standard.

\section{Activity Performance}

Table 7 and 8 show KAI had higher collection period compared to THSR. THSR started from 2.83 days in 2011. In the next following years, the number fluctuated from 3.88 days in 2012, 3.63 days in 2013, and 2.15 days in 2014. In 2015, THSR reached its lowest point in 1.48 days. Meanwhile, KAI started 2011 in 17.59 days then sharply decreased to 15.46 days. It reached its bottom level in 2013 to 7.04 days but had a dramatically rise in 2014 to 17.03 days, before finally fell to 13.08 days in the next following year. In short, collection period of both companies meets the minimum standard of the Decree which is less than 60 days. The companies would receive its payment owed in 13.08 days for KAI and 1.48 days for THSR.

Table 7 and $8 \mathrm{KAI}$ and THSR had similar trend of inventory turnover in five years from 2011 until 2015. In 2011, inventory turnover of KAI was 34.98 days. Similarly, THSR was 35.38 days. In the 2012, THSR slightly decreased to 32.29 days, while KAI slightly increased to 36.28 days. In the next following years, both companies' inventory turnover fell to 32.69 days and 29.18 days, respectively. THSR moderately decreased to 26.55 days in 2014, while KAI had sharp decrease to 21.00 days in the same year. In 2015, both companies dropped to 16.18 days and 15.15 days. In conclusion, both companies meet the minimum standard of the Decree which is less than 60 days for inventory turnover. Itmeans, inventories of both KAI and THSR would be sold and replaced in about 15 to 16 days.

Table 7 and 8 show that KAI had higher TATO than THSR. Meanwhile, THSR had stable trend since 2011 to 2015. In 2011 the company was in 13.36 per cent. In the next following year, THSR fell to 8.28 per cent then fell again in 2013. In 2014 , the company finally rose up to 7.85 per cent and 11.03 per cent in 2015. On the otherhand,
KAI's TATO was 121 per cent in 2011, far way higher than THSR. Then it decreased in the following years to 103 per cent and reached its lowest point in 2013 to 65 per cent. In the next following years, it increased and remained steady in 83 per cent. In short, both of the companies could not meet the minimum standard of the Decree which is 120 per cent for TATO. It means, both KAI and THSR could not generate their revenue effectively since their TATO achievements are far below the minimum standard.

\section{Solvency Performance}

Table 7 and 8 show KAI had higher solvency than THSR from 2011 to 2015. In 2011, THSR's solvency was 6.78 per cent while KAI's was 65.08 per cent. THSR's solvency slowly increased in the next following years until finally reached its peak in 2015 to 11.89 per cent. Meanwhile, KAI's solvency decreased to 59.41 per cent in 2012 and reached its lowest point in 2013 to 39.22 per cent. In the next following years, the company slowly rose to 40.99 per cent and 40.58 per cent in 2014 and 2015, respectively. It is shown that KAI almost meet the minimum standard of the Decree which is between 30 to 40 per cent for solvency. It means, KAI has ability to pay its debt, so does THSR. But KAI has a healthier financial health and viability than THSR since the ratio of THSR in 2015 was far below PT KAI.

\section{Validation Testing}

Table 7 above shows the test results during 2011 to 2015 of KAI. Overall, there were fluctuations in the total score during 2011 to 2015 are $33.5,38.5,34,39.5,44.5$.

In the table 9 , the weight calculated by using the formula as Weight $=\left(\frac{\text { Total Score }}{\text { Total Weight }}\right) \times 100 \%$. The result shows the healthy category during the periods are A in 2011, A in 2012, A in 2013, A in 2014, and AA in 2015.

Table 9 shows the test results for THSR. Overall, there were stable total score during 2011 to 2015 are $26,37,24.5,28.5$, and 33 . In the table 10 , the weight also calculated by using the formula as Weight $=\left(\frac{\text { Total Score }}{\text { Total Weight }}\right) x 100 \%$. The result is shown 
Table 9. Total Score for PT Kereta Api Indonesia (KAI) 2011-2015

\begin{tabular}{|c|c|c|c|c|c|c|}
\hline Year & Total Score & Total Weight & Weight & Value & Level & Category \\
\hline 2015 & 44.5 & 50 & 89 & $80<\mathrm{TS}<=90$ & AA & Healthy \\
\hline 2014 & 39.5 & 50 & 79 & $65<\mathrm{TS}<=80$ & A & Healthy \\
\hline 2013 & 34 & 50 & 68 & $65<\mathrm{TS}<=80$ & A & Healthy \\
\hline 2012 & 38.5 & 50 & 77 & $65<\mathrm{TS}<=80$ & A & Healthy \\
\hline 2011 & 33.5 & 50 & 67 & $65<\mathrm{TS}<=80$ & A & Healthy \\
\hline
\end{tabular}

Table 10. Total score for Taiwan High Speed Rail (THSR) 2011-2015

\begin{tabular}{|c|c|c|c|c|c|c|}
\hline Year & Total Score & Total Weight & Weight & Value & Level & Category \\
\hline 2015 & 33 & 50 & 66 & $65<\mathrm{TS}<=80$ & A & Healthy \\
\hline 2014 & 28.5 & 50 & 57 & $50<\mathrm{TS}<=65$ & BBB & Less Healthy \\
\hline 2013 & 24.5 & 50 & 49 & $40<\mathrm{TS}<=50$ & BB & Less Healthy \\
\hline 2012 & 37 & 50 & 74 & $65<\mathrm{TS}<=80$ & A & Healthy \\
\hline 2011 & 26 & 50 & 52 & $50<\mathrm{TS}<=65$ & BBB & Less Healthy \\
\hline
\end{tabular}

in table 10, which shows category of BBB (less healthy) in 2011, A (healthy) in 2012, BB (less healthy) in 2013, BBB (less healthy) in 2014, and A (healthy) in 2015.

\section{CONCLUSION, LIMITATION AND RECOMMENDATION}

The study concerns about four classifications of ratio measurement that includes profitability, liquidity, activity solvency ratios based on the decree of the Ministry of SOEs RI, No.KEP100/MBU/2002 about financial health assessment of railway industries from Indonesia and Taiwan. As the major player of the railway industry and state-owned enterprise since its establishment, KAI showed a good performance in financial aspect. Although there was a decreasing in its performance in 2013 compared to the previous years, but KAI could rise again in the two following years until it finally reached its peak in 2015 to 89 with level A and categorized as healthy. As the only major player in Indonesia, it is important for the company to be compared to similar industry in other country.

Taiwan High Speed Railway (THSR) is chosen since the company had similar background to KAI. Based on the calculation, the company do not have a financial performance as good as KAI. In 2013, similar to KAI, THSR also suffered in lowest weight value, thus categorized as less healthy. But then, in the next following years, the trend was similar to KAI, the THSR reached its peak in 2015 to 66 and categorized as healthy. Even so, KAI is still superior compared to THSR in the term of their financial performance in 2011-2015 in the framework of the Decree. This result implied that both of the companies could recover from their crisis in 2008, as both KAI and THSR suffered from global economic recession. Yet, however, based on the calculation, KAI had a better recovery compared to THSR.

This study has expanded the literature about financial evaluation in the real working world. In near future, it is suggested to carry out a research with many companies from railway industry to get more generalize result. Since the focus is only on one industry, it is worth to explore it on a wider scale and find out if different industry yields the same result.

The study also has added the knowledge in the financial literature. It is showed that even though there was an economic crisis, the company could stand up and had better performance than other similar company; not to mention the economics growth and political situation of Indonesia. Generally, both companies have a challenge in asset utilization and inventory management. Therefore, this study is useful for the managers to tackle the 
challenges and improve its efficiency. In addition, the present study could be used as an insight for managers and investors in railway industry to consider Indonesia as a potential business.
Furthermore, this study could be policy options might be taken to improve both urban railways' performance.

\section{RE F ERENCES}

Alexander, G. J., and Buchholz, R. A. (1978). Corporate social responsibility and stock market performance. Academy of Management Journal, 21 (3), 479-486.

Anthony, N. R., Hawkins, F. D., \& Merchant, A. K. (2011). Accounting: Text and Cases, Thirtheenth Edition. New York City, New York: McGraw-Hill.

Arduin, J.P., Ni, J. (2005). French TGV network development. Japan Railway \& Transport Review, 40, pp. 22-28

Cheng, Y. H. (2010). High-speed rail in Taiwan: New experience and issues for future development. Transport Policy, 17, 51-63.

Cochran, P. L., Wood, R. A. (1984). Corporate Social Resposibility and Financial Performance. Academy of ManagementJournal, 27(1), 42-56.

Daryanto, W. M., Nurfadilah, D. (2018). Financial Performance Analysis Before and After the Decline in Oil Production: Case Study in Indonesian Oil and Gas Industry. International Journal of Engineering \& Technology, 7 (3.21), 10-15.

Daryanto, W. M., Samidi, S. (2018). Measuring the Financial Performance of Enterprises Under Ministry of Energy and Mineral Resources (EMR) an Indonesia Experience. International Journal of Engineering \& Technology, 7 (3.21), 16-23.

Dirjen Perkeretaapian, Kementerian Perhubungan. Sejarah Perkeretaapian Indonesia. Retrieved from http://djka.dephub.go.id/berita?id=5

Gómez-Ibáñez, J.A., Ginés de Rus. (2006). Competition in the Railway Industry: An International Comparative Analysis. Cheltenham, UK: Edward Elgar Publishing Limited.

Kumbirai, M., \& Webb, R. (2010). A financial Ratio Analysis of Commercial Bank Performance in South Africa. African Review of Economics and Finance, 2 (1), 30-53.

Lan, Joe. (2012). 16 Financial Ratios for Analyzing a Company's Strengths and Weaknesses. Retrieved from https://www.aaii.com/journal/article/16-financial-ratios-for-analyzing-a-companys-strengthsand-weaknesses.touch

McGuire, J. B., Sundgren, A., \& Schneeweis, T. (1988). Corporate social responsibility and firm financial performance. Academy of managementJournal,31(4), 854-872.

Mizutani, F. \& Shoji, K. (1997). A Comparative Analysis of Financial Performance: Indonesia and Taiwan Urban Railways. International Journal of Transport Economics, 24 (2), 207-239.

Pratama, S. (2017). Measuring Financial Performance of PT. Pos Indonesia During The E-Commerce Booming. International Journal of Business Studies, 1 (1), 32-40.

Takatsu, T. (2003). Sustainable City Development \& Asian Urban Railways. Japan Railways \& Transport Review, 35, pp. 4-15.

Vance, S. C. (1975). Are socially responsible corporations good investment risks. Management review, 64(8), 19-24.

Waddock, S. A., and Graves, S. B. (1997). The corporate social performance- financial performance link. Strategic Management Journal, 18(4), 303-319.

Washington, H. Lee. (2001). Financial distress reporting: Bringing a user focus to business reporting. ProQuest Dissertations: UMI. 